\title{
Internet resources on disasters
}

\author{
By Linda Musser and Lisa Recupero
}

\section{Erupting now at a screen near you}

D isasters fascinate people. They induce feelings of amazement and fear, and provide examples of courage, folly, and tragedyin a sense, all the aspects of great drama. Disasters are media events and frequently inspire Hollywood as most recently evidenced by the movies Twister, Dante's Peak, and Volcano. For any or all of these reasons, disasters are also popular topics at the reference desk. Yet good, comprehensive, timely tools to answer "disaster" questions are few to nonexistent. The Internet has become one of the best reference tools available for questions relating to disasters. We highlight here some of the premier Web sites on disasters that are useful in a reference setting. While there are many sites with information about specific events (e.g., the Mt. St. Helens eruption), our focus is on those that provide a broad view of disasters. First we describe "metasites" which cover multiple types of disasters, then we describe sources of clisaster information by the type of disaster.

\section{Metasites}

- Earthweek. Subtitled "A Diary of a Planet," this site uses maps and symbols to highlight the location and type of natural and manmade events on a weekly basis. In addition to disasters such as earthquakes, short entries describe other unusual events such as temperature extremes and wild animal attacks. Earthweek is archived back to October 1995. Access: http://www.slip.net/ earthenv/.
- Disaster Relief. A joint Web site between IBM, the American Red Cross, and CNN, this site brings together media coverage and additional data about world disasters. You can produce a custom list of news stories by type of disaster (building collapse, epidemic, tsunami, etc.), by location and by date. Access: http://www disasterrelief.org/.

- HazardNet. A project of the International Decade for Natural Disaster Reduction, this site contains maps and information on recent events by type of disaster. Access: http://hoshi.cic. sfu.ca/ hazard/.

- Severe Weather Data. The title of this site is deceptive, as it provides links to current watches, warnings, advisories, and bulletins for all types of natural disasters including tornadoes, wind, fog, flooding, sea ice, fire, earthquakes, avalanches, and more. Most postings are U.S. locations. Access: http://asp1.sbs.ohiostate.edu/severetext.html.

- Insurance Information Institute. This provides information on the worst worldwide disasters in terms of deaths and losses caused by earthquakes, hurricanes, tornadoes, floods, and fires. There is also a "ten worst monetary losses in the U.S." list under each category. Access: http://www.iii.org/media/CATAS.HTM.

- ReliefWeb. ReliefWeb is a project of the United Nations Department of Humanitarian Affairs. It provides information about ongoing emergencies and crises worldwide; some information about past crises is also available. Information includes situation reports detailing the date, type, and extent of the disaster, maps, damage estimates, requests for assistance and donations, numbers of people affected, and more. Access: http://www.reliefweb.int/. 
- International Federation of Red Cross and Red Crescent Societies. This site features reports of activities, situation reports, and appeals for assistance worklwide. It also includes the annual publication World Disasters Report, which analyzes humanitarian crises of the past, present, and future in tables, text, and figures. Data include annual and historic disasters by date and country, number of victims by country, and more. Access: http://www.ifrc.org

- Volunteers in Technical Assistance (VITA). This site provides links to situation reports of natural and man-made disasters from countries that have requested support from VITA. It includes links to situation reports from other organizations as well. Access: http://www. vita.org/

- Federal Emergency Management Agency. This site focuses on U.S. disasters. It provides extensive information about historic hurricanes and current disaster situations, federally declared disasters, news releases, radio spots, video clips, and fact sheets. A searchable database, called the Global Emergency Management System, indexes disaster-related Web sites. Access: http://www.fema.gov/.

- Natural Hazards Center. This is the best site for comprehensive information relating to natural disasters. Included are extensive quick response reports of both natural and man-made disasters, the full text of many of the center's publications, lists of organizations, and extensive links to other Internet sites. Access: http:/ /www.colorado.edu/hazards.

- Yahoo-Disasters page. Yahoo's index to disaster links on the Web is a useful compilation of miscellaneous sources for disaster events. Access: http://www.yahoo.com/ Society_and_Culture/Environment_and_Nature/ Disasters/

\section{Meteorological disasters Metasites}

- National Storm Prediction Center. This site provides statistics on tornadoes and other severe storms including monthly totals and averages, and killer tornado statistics for the U.S. Its historical online archive contains data on tornadoes, hail, and convective winds. Statistics are given by state from the 1940 s to 1995 for injuries, fatalities and costs, overall rankings, and more. Most files in the archive must be downloaded and unzipped. (For data after 1995 see the NCDC Web site, described below.) Access: http://www.nssl.noaa.gov/ spc/.
- Tornado and Storm Research Organisation. TORRO, a private British research organization, has compiled lists of all-time weather extremes for Britain for smog, precipitation, wind, floods, and more, as well as annual synopses of severe weather events in Europe and the UK. Access: http:// www.torro.org.uk/.

- USA Today Weather Page. This site features means, extremes, weather records, and recent weather highlights for locations around the world. It includes information and statistics on weather events such as hurricanes, tornadoes, water spouts, and severe storms. Excellent explanations of weather phenomena are also provided. Access: http://www.usatoday. $\mathrm{com} /$ weather/wfront.htm.

Additional metasites for meteorological diSasters include the National Climatic Data Center for detailed reports of extreme U.S. weather events (access: http://www.ncdc. noaa.gov/) and the Societal Aspects of Weather site which contains economic and casualty clata for various weather phenomena (access: http://www.dir.ucar,edu/esig/socasp/).

\section{Hurricanes and tropical storms}

- Hurricane/Tropical Data. The Purdue University Weather Processor provides storm track charts and text-based tables for storms in the Atlantic (from 1886) and the Eastern (from 1949) and Western (from 1945) Pacific. There is a composite chart for each season as well as for each individual storm. The site also provides extensive links to satellite and radar imagery. Access: http://wxp.atms.purdue.edu/ hurricane.html.

- National Hurricane Center. This site provicles current and historic tropical cyclone, hurricane, and high seas data along with high wind/wave alerts and ocean weather for mariners and aviators. Access: http://www.nhc. noaa.gov.

- Hurricanes, Typhoons, and Tropical Cyclones FAQ. This site provides lists of the costliest, deadliest, longest, and most intense events as well as other records and data about tropical storms. Access: http://www.aoml. noaa.gov/hrd/tcfaq/tcfaqHED.html.

\section{Droughts and floods}

- National Drought Mitigation Center. This site contains links to current U.S. drought forecasts and advisories. Other data include moisture and vegetation indices, water supply 
conditions, and global drought headlines. The "Drought Climatology" section has more than 100 years of U.S. drought data mapped and graphed. Access: http://enso.unl.edu/ndmc.

- Dartmouth Flood Observatory. The "Flood Archive" has a worldwide index map, report summaries, and a table that displays the start and end date, number of deaths, damage estimates, and amount of land impacted for flood events from 1994 to the present. The site also provides numerous satellite images of flood events. Access: http://www.dartmouth. edu/artsci/geog/floods/.

\section{Tornadoes and severe storms}

- The Tornado Project Online. This commercial site links to descriptions of current (and some historic) tornado events in the U.S. Top ten lists of tornadoes by number of deaths, size, etc., are provided. It also contains an explanation of the Fujita tornado intensity scale. Access: http://www tornadoproject.com/.

- The Storm Chaser Homepage. This site is usually one of the first to post eyewitness accounts of severe weather events occurring in the U.S. It is also a good source for images of tornadoes and severe storms. Access: http://taiga.geog.niu.edu/chaser/chaser.html.

\section{Lightning and wildfires}

- National Lightning Safety Institute (NLSI). NLSI is a nonprofit research organization whose site contains lightning safety information, statistics on losses and damage caused by lightning, and cuick lightning facts. Access: http://www.lightningsafety.com/.

- National Interagency Fire Center. This site features wildland fire information for the

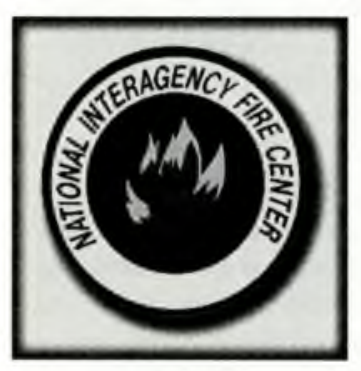
U.S. It includes weekly incident reports by region, summaries of previous fire season statistics including the largest fires of that season, plus ten-year averages for fires. Access: http://wow nifc.gov.

\section{Geophysical disasters \\ Earthquakes, tsunamis, and asteroids}

- National Earthquake Information

Center. This is the site for information and maps on the latest earthquakes to occur on the globe. It features lists of the largest, deadliest, and costliest earthquakes, an interactive database that produces customized reports, and much more. Access: http://wwwneic.cr.usgs.gov/.

- Asteroid and Comet Impact Hazards. This site contains a list of upcoming close encounters with asteroids. It also has an image gallery of impact craters and other information relating to

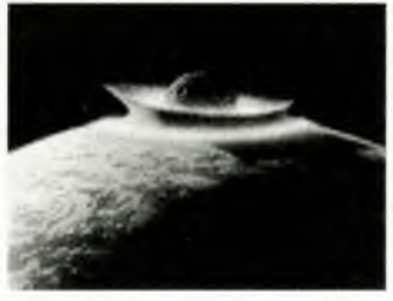
cometary and asteroid impacts. Access: http:// ccf.arc.nasa.gov/sst/.

- The IRIS Consortium. IRIS is a university research consortium that collects and distributes seismic data. A clickable epicenter map supplies information on events that have occurred in the last 30 days. Detailed event-specific data files and maps are available via the IRIS SPYDER clatabase for events since October 1996. Access: http://widow.iris.washing ton.edu/HQ/HQ.htm.

- Recent Seismic Events Bulletins. This site is part of the UN Prototype International Data Centre for monitoring the Global Test Ban Treaty. Bulletins can be displayed in various formats and by various seismic detection methods. An interactive epicenter map can be customized by location, time, projection, etc. $A C$ cess: http://www.cdidc.org:65120/web-bin/ recentevents.

- Tsunami. This site provides access to information on tsunami events as well as access to near-real time events via a link to the West Coast/Alaska Tsunami Warning Center. Access: http://www.geophys.washington.edu/ tsunami/welcome.html.

\section{Volcanoes}

- Michigan Technological University Volcanoes Homepage. This site offers exceptional information on current volcanic activity, remote sensing images of volcanoes, and links to other volcano-related Web sites. The coverage includes location/geological setting, topographic maps and air photos, meteorology, type of edifice, petrology, eruption history, bibliography, and images for indexed volcanoes. $A C$ cess: http://www.geo.mtu.edu/volcanoes/.

- Volcano World. Check out "What is erupting now" to see lists of current volcanic activity and information on the eruptions. You can also access images of volcanoes by region 
and on other planets. If you need help with a stumper volcano reference question, visit the 101 Frequently Asked Questions in the "Ask a volcanologist" section. Access: http:// volcano.und.nodak.edu/vw.html.

- The Electronic Volcano. Hosted by Dartmouth College, this site maintains an excellent bibliography of volcanological literature. An index page provides links to information by volcano name or by country. Access: http:// www.dartmouth.edu/ volcano/.

- USGS Volcano Observatories. The U.S. Geological Survey has a series of regional volcano observatories in the Pacific Rim which are excellent for locating regional volcanic information. They include the Cascades Volcano Observatory for volcanoes in the Cascade Range including extensive information on $\mathrm{Mt}$. St. Helens and its eruptions (access: http:// vulcan.wr.usgs.gov/); the Alaska Volcano Observatory for volcanoes along the Aleutian arc (access: http://www.avo.alaska.edu/); and the Hawaiian Volcano Observatory for Hawaiian arc volcanoes (access: http:// hvo.wr.usgs.gov/).

There are numerous sites about volcanoes on the Web. A few others of note include the Smithsonian's Global Volcanism Program (access: http://www.nmnh.si.edu/gvp/), Italy's Volcanoes (access: http://www.geomar.de/personal/bbehncke/STROMBOLI.html), and the Volcanic Homepage (access: http://www. aist.go.jp/GSJ/ jdehn/v-home.htm).

\section{Mass movements}

- Cyberspace Snow and Avalanche Cen-

ter. This site provides current conditions and avalanche bulletins for mountainous regions all over the world as well as an incident report table for the current season that includes location, fatalities, activity that sparked the event, and more. There are also numerous statistics and an archive of eye-witness accounts and reports. Access: http://www.csac.org/.

- Westwide Avalanche Network. Main tained by the American Association of Avalanche Professionals, this site contains extensive information on current and past avalanche seasons, detailed accident reports, and a photo libraty of avalanche events. Access: http:// www.avalanche.org/toc.htm.

\section{- National Landslide Information Cen-}

ter. This site provides access to factsheets, reports, and images of specific U.S. landslide events. Access: http://geohazards.cr.usgs.gov/ html_files/nlicsun.html.

\section{Biological disasters Diseases}

- National Center for Infectious Diseases. Maintained by the U.S. Centers for Disease Control, this site provides information about existing and new or emerging infectious diseases. Lists of diseases and information about them are provided. Most useful is the section called "Traveler's Health," which contains information about disease outbreaks by occurrence and by geographic region. Access: http:// www.cdc.gov/ncidod/ncid.htm.

- Outbreaks. Provided by the World Health Organization, this site summarizes disease outbreaks around the world and includes disease fact sheets and health information for travelers. Access: http://www.who.ch/ outbreak/outbreak_home.html. When the articles are posted to the Web (http:/ /www.ala.org acrl/resrces.html) hypertext links are made to each source.

\section{Topic}

Grants and foundations

Classical studies

Environmental resources

Journalism and communications

Ready reference

Chemistry resources

Gay and lesbian studies

American and international studies

1996 election resources

Biology resources

Agriculture resources
Issue

May 1997

April 1997

March 1997

February 1997

January 1997

December 1996

November 1996

October 1996

September 1996

July/August 1996

June 1996

\section{Famines}

- Global Information and Early Warning System on Food and Agriculture. Maintained by the Food and Agriculture Organization of the United Nations, this site provides information on world food supplies, prices, food shortages, and crop damages, both currently and in the recent past. $A c$ cess: http://www.fao.org/WAICENT/ FAOINFO/ECONOMIC/giews/ english/giews.htm. 
- World Food Programme (WFP). The WFP Emergency Reports provides weekly updates on WFP emergency operations. The site also includes historic food aid statistics, transportation and logistics statistics, and vulnerability assessment maps for crisis areas. Access: http://www.wfp.org/.

- Migratory Pests. This site tracks information about migratory pests such as the desert

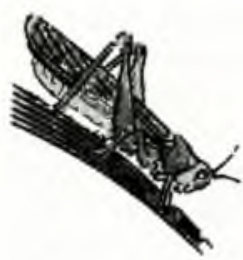
locust. It maintains situation reports and maps of infestations. Access: http:// faowfsoa.fao.org/www. fao org/W A I CENT/ FAOINFO/AGRICULT/ A GP/AGPP/Locusts/ Default.htm.

\section{Technological disasters Accidents}

- National Transportation Safety Board. This offers data on accidents in the U.S., current and historic, by transportation modeaviation, highway, marine, rail, pipeline-and hazardous materials. Access: http://www.ntsb. gov/.

Other sites of note related to transportation disasters include Major Airline Disasters for information on worldwide events (access: http: //www.infosites.net/dnet/dnetGOjg/Disasters. htm), and the Aviation Accident Site which contains radar images and cockpit voice record- ings (access: http://members.aol.com/ chrisk 747 /index.html).

- Emergency Response Notification System. This site, maintained by the U.S. Environmental Protection Agency, features a database of hazardous substance releases in the United States. It contains information and facts on types of spills, where spills occurred, the top ten spills, numbers of spills by location, and so on. Access: http://www.epa.gov/ERNS/ index.html.

- United States Fire Administration. This site maintains detailed statistics on urban fires in the U.S. from 1985 to the present. $A C$ cess: http://www.usfa.fema.gov/who.htm.

\section{Terrorism and war}

- The Terrorism Research Center. This site contains terrorist profiles, a calendar of significant dates for terrorist activities, and links to sites containing descriptions of terrorist incidents and travel advisories. Access: http: //www.terrorism.com/terrorism/index.html.

- Bomb Data Center. The FBI maintains a repository of bomb incident data which are summarized here with data on U.S. incidents since 1990. Access: http://www.fbi.gov/lah/ bomsum/eubdc.htm.

- United Nations High Commissioner for Refugees. This site offers various data on refugee populations from 1985 onward. Access: http://www.unhcr.ch.

\section{C\&RL News 30th anniversary quiz}

Here is the next installment of the CERL News 30th anniversary quiz. Test your recollection of events that have been reported in the News since 1966.

1. How many books did the earthquake which hit Guam on August 9, 1993 (measuring 8.2 on the Richter scale) knock off the shelves at the University of Guam library?
2. What is one often unappreciated role of an academic librarian?

3. What is one drawback of compact shelving?

4. When did the ERIC Clearinghouse on Information Resources move to Syracuse University?

5. What was the title of the book with the earliest imprint to go into space? What book was the first to orbit the earth?

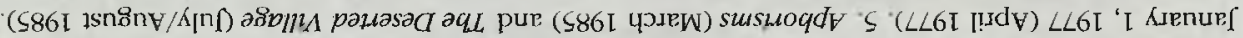

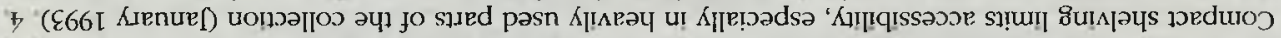

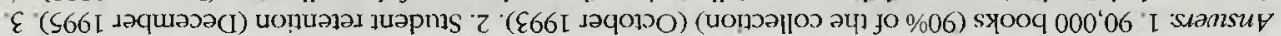

